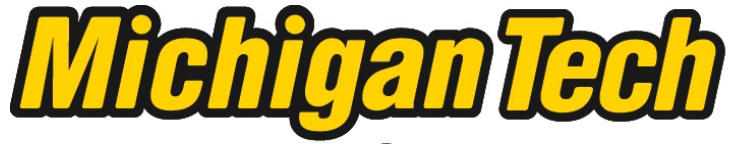 \\ Michigan Technological University Create the Future Digital Commons @ Michigan Tech
}

Dissertations, Master's Theses and Master's Reports - Open

Dissertations, Master's Theses and Master's

Reports

2014

\section{A STUDY OF A LANDSLIDE IN BIRMINGHAM, ALABAMA}

Caitlin L. Bukovitz

Michigan Technological University

Follow this and additional works at: https://digitalcommons.mtu.edu/etds

Part of the Civil Engineering Commons, and the Construction Engineering and Management

Commons

Copyright 2014 Caitlin L. Bukovitz

\section{Recommended Citation}

Bukovitz, Caitlin L., "A STUDY OF A LANDSLIDE IN BIRMINGHAM, ALABAMA", Master's report, Michigan Technological University, 2014.

https://doi.org/10.37099/mtu.dc.etds/832

Follow this and additional works at: https://digitalcommons.mtu.edu/etds

Part of the Civil Engineering Commons, and the Construction Engineering and Management Commons 


\title{
A STUDY OF A LANDSLIDE IN BIRMINGHAM, ALABAMA
}

By

Caitlin L. Bukovitz

\begin{abstract}
A REPORT
Submitted in partial fulfillment of the requirements for the degree of MASTER OF SCIENCE

In Civil Engineering
\end{abstract}

MICHIGAN TECHNOLOGICAL UNIVERSITY

2014

() 2014 Caitlin L. Bukovitz 
This report has been approved in partial fulfillment of the requirements for the Degree of MASTER OF SCIENCE in Civil Engineering.

Department of Civil and Environmental Engineering

\author{
Report Advisor: $\quad$ Stanley Vitton \\ Committee Member: $\quad$ Ralph Hodek \\ Committee Member: $\quad$ Jason Gulley \\ Department Chair: $\quad$ David W. Hand
}




\section{TABLE OF CONTENTS}

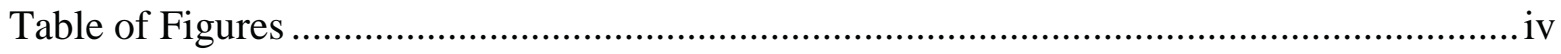

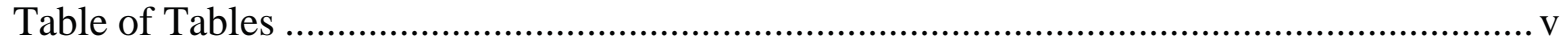

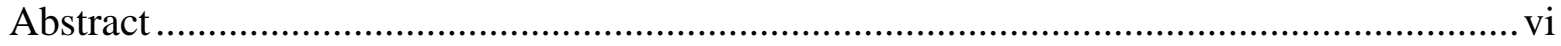

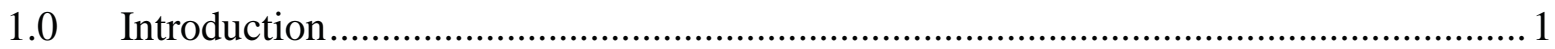

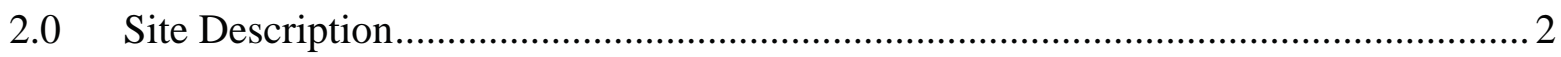

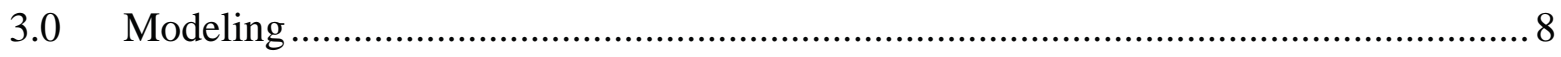

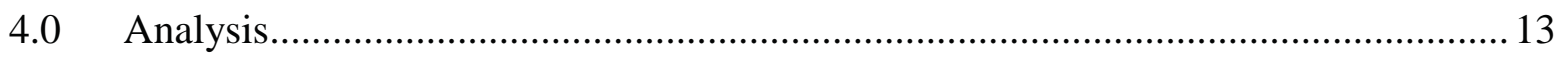

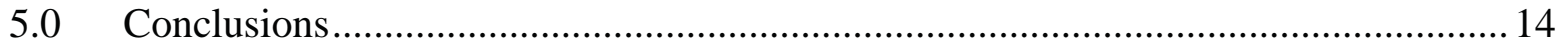

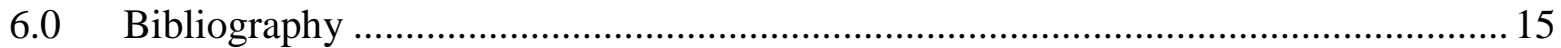

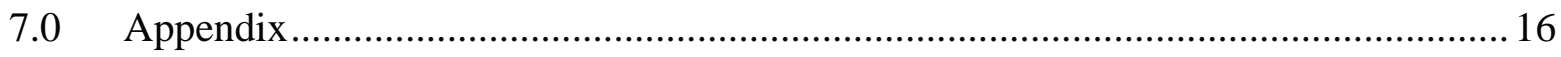




\section{Table of Figures}

Figure 1: The Mountain Top Apartments and the construction site directly after the two

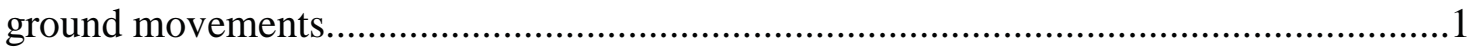

Figure 2: Map of area of interest. ${ }^{[6]}$ See Appendix for permissions............................... 3

Figure 3: Map of Alabama. ${ }^{[6]}$ See Appendix for permissions.........................................

Figure 4: Map of the geology of the area of interest. ${ }^{[9]}$ See Appendix for permissions..3

Figure 5: Assumed stratigraphy from Boring 1. ${ }^{[2]}$ See Appendix for permissions..........5

Figure 6: Mountain top apartments and the block slides outlined. ${ }^{[2]}$ See Appendix for

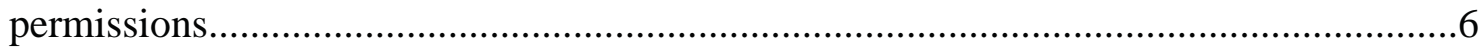

Figure 7: Design of cut slope drawn from information in the designing company

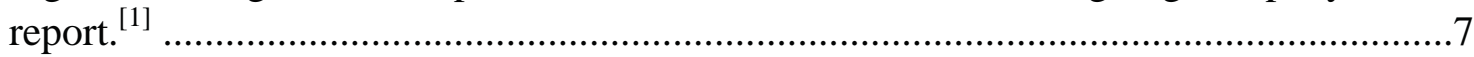

Figure 8: Figure 2 from Crane's paper showing the fracture systems. See Appendix for

permissions................................................................................................... 7

Figure 9: Baseline model that represents as designed factors from the designing

company

Figure 10: Demonstration of RocPlane's fracture input system

Figure 11: The model showing a factor of safety of 1.0 at 50 feet with fractures and water pressure at the base of the fractures

Figure 12: Graph of the factor of safety versus slope height with fractures and water pressure at the base of the fractures.

Figure 13: RocPlane results for the baseline model................................................18

Figure 14: RocPlane results for the as failed model...............................................19 


\section{Table of Tables}

Table 1: The strength parameters of the soil and rock in the area of interest...................6 


\section{Abstract}

In 1988 a landslide occurred at a construction site in Birmingham, Alabama in which a portion of the construction site required excavating a rock slope with a group of apartments that were located at the top of the slope. During construction, two separate landslides occurred causing one and half of the apartment buildings to collapse downslope. The slope failure was investigated by two firms. One firm investigated the site conditions and the second firm investigated the design of the cut slope. The main concerns in the investigation were (1) the lack of consideration for the existing joint system, (2) using averaged the strength parameters, (3) the possibility of damaging the slope with blasting, and (4) the potential that there were underground mines at the site. The Rocscience program RocPlane was used to model the in situ conditions and the excavation. The model showed that the joint system's pore water pressure was most likely the main factor in the failure. 


\subsection{INTRODUCTION}

In 1988, a landslide occurred in Birmingham, Alabama, during the construction of the Eastwood Festival Mall. The construction site was located on the southeast side of the Red Mountain, a ridge running northeast-southwest consisting of Silurian sedimentary rock and part of the southern terminus of the Valley and Ridge Province of the Appalachia region. The Red Mountain is composed of sedimentary rocks including claystone, siltstone, sandstone and hematite layers which have been mined for iron ore over the past one hundred and fifty years. The rock layers are weathered and are dipping at approximately $20^{\circ}$. The mall was constructed at the base of the Red Mountain, while the Mountain Top Apartments were located on top of the Red Mountain and consisted of 32 apartments. The slope under construction and a portion of the apartments are shown in Figure 1. The slope between the Mountain Top Apartments and the Festival Mall was designed as a cut and fill excavation with a final slope of $45^{\circ}$ and a height of 80 feet. The rock layers were dipping directly into the proposed cut, which raised concerns about the stability of the slope especially during construction of the final slope. Additionally, weathered claystone rock layers located within the slope were determined to be weaker than the surrounding rock layers. To monitor the slope, inclinometers were installed and the readings were recorded daily during construction.

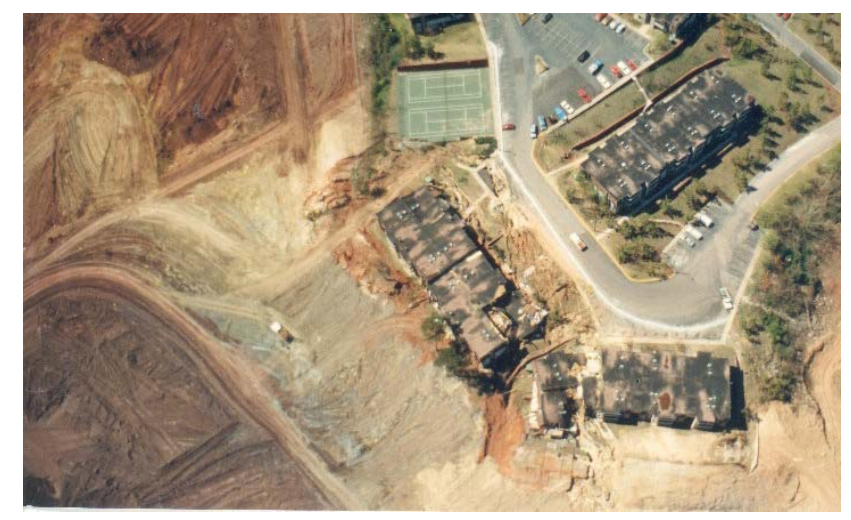

Figure 1: The Mountain Top Apartments AND the CONSTRUCTION SITE DIRECTLY AFTER THE TWO GROUND MOVEMENTS.
On March $14^{\text {th }}, 1988$, during construction of the cut slope, slope failed along the claystone layer. At the time of failure, the slope had been excavated to about 65 feet. The first failure caused one of the apartment buildings to slide downslope. The day after the first 
failure, a second landslide broke one of the other buildings in half and brought part of the building downslope. Fortunately, the accident only resulted in one minor injury to a resident of the apartments and no construction workers were injured. After the landslides, the construction site was shut down and a failure investigation was conducted.

After the two slope failures, two companies were hired to investigate the cause of the slope failures. One firm performed site exploration while the other reviewed the slope design and test data that the design company provided. According to the exploratory company, the slope failed along a thin layer of claystone rock. Personnel at the site also noted that seeping water could be seen during the excavation. During the investigation, rock jointing was found and blasting was also considered an issue. Additionally, it was discovered that the inclinometers showed that the slope was slipping prior to the failure. The two investigating companies attributed the failure to the weak layer of claystone and the jointing system within the slope, but the actual causes of the slope failures were never confirmed.

The following report will describe modeling of the slope failure in an attempt to find the main reasons for the failure. The modeling consisted of a baseline case using the geotechnical data from the design company. After completing the initial analysis, information from the failure investigation was added to the model, consisting of the jointing system and pore water pressure that had not been considered in the original design.

\subsection{SITE DESCRIPTION}

Birmingham, Alabama is located at a latitude of $33.524755^{\circ} \mathrm{N}$ and a longitude of $86.81274^{\circ} \mathrm{W}$ (Figure 2). ${ }^{[6]}$ The construction site is located between Crestwood 
Boulevard and Cresthill Road (Crestwood Boulevard is also highway 78 and route 4) as shown in Figure 3.
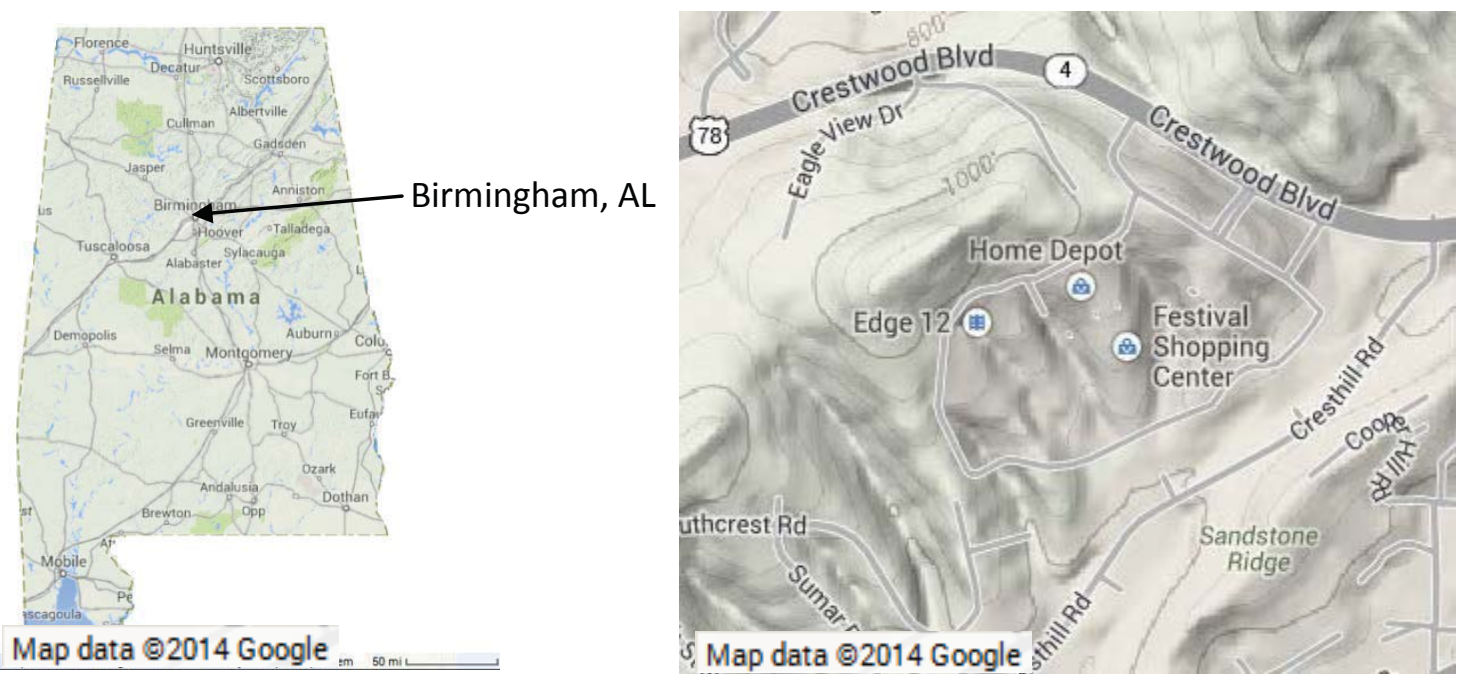

Figure 2: MaP OF Alabama. ${ }^{[6]}$ SeE APPENDIX FOR PERMISSIONS.

\begin{tabular}{|c|c|}
\hline Oal & Alluvium and low terrace deposits \\
\hline $\mathbb{P p p}$ & Pottsville Formation \\
\hline PMMpw & Parkwood Formation \\
\hline M & Floyd Shale \\
\hline Mb & Bangor Limestone \\
\hline Mth & Hartselle Sandstone \\
\hline Mpm & Pride Mountain Formation \\
\hline Mntip. & Tuscumbia Limestone, Fort Payne Chert, and Maury Form \\
\hline Defm & Chattanooga Shale and Frog Mountain Sándstone \\
\hline Srm & Red Mountain Formation \\
\hline Oe & Chickamauga Limestone \\
\hline Oca & Attalla Chert Conglomerate Member: Chickamauga Limest \\
\hline ock & Knox Group undifferentiated \\
\hline EKt & Ketona Dolomite \\
\hline \& & Conasauga Formation \\
\hline
\end{tabular}

Figure 3: MAP OF AREA OF INTEREST. ${ }^{[6]}$ SEE APPENDiX For PERMISSIONS.

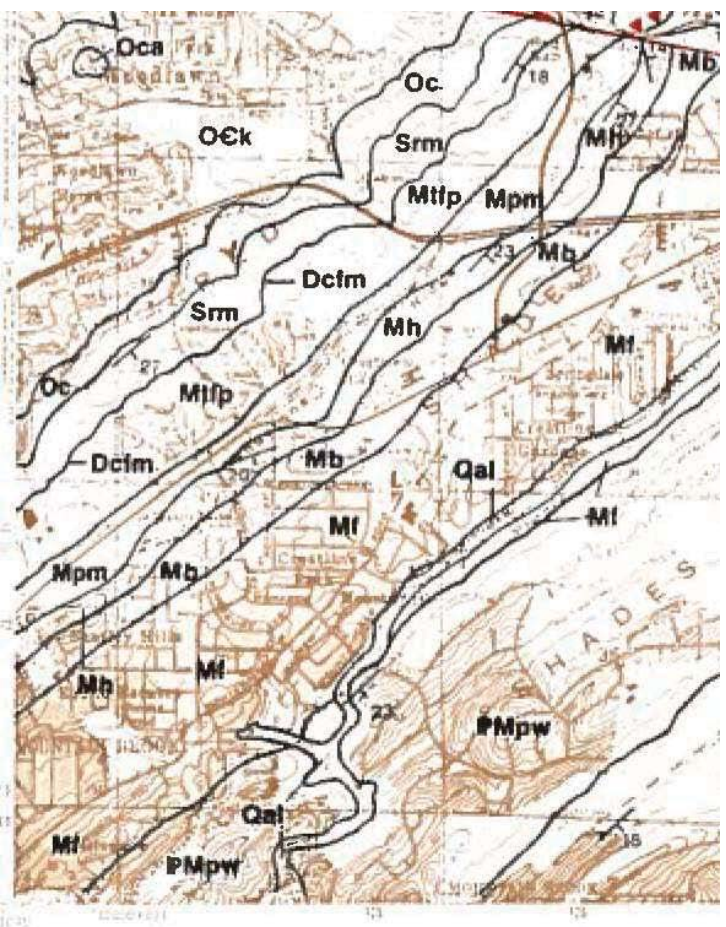
BASE TOPOGRAPHIC MAP BY USGS 1959 PHOTO REVISED 1970

FigURE 4: MAP OF THE GEOLOGY OF THE AREA OF INTEREST. ${ }^{[9]}$ SEE APPENDIX FOR PERMISSIONS. 
The geology of Birmingham, Alabama, is part of the Valley and Ridge Province of Appalachia and consists of the following formations: Red Mountain Formation, Chattanooga Shale and Frog Mountain Formation, Hartselle Sandstone, Pride Mountain Formation, Tuscumbia Limestone, Fort Payne Chert, and Maury Formation, and Bangor Limestone. A stratigraphic column illustrating these formations is shown in Figure 4. The Red Mountain Formation contains shales, siltstone, and clay bedding layers with hematite interspersed in the bedding. The claystone layers are mostly the result of weathering of the rocks and are generally thinner than 10 feet. Many of the upper layers are weathered to various degrees. Some areas are also highly fractured. The Chattanooga Shale and Frog Mountain Formation is composed of a thinly bedded shale and a sandstone layer which is highly fractured in places and contain some chert. The shale beds are generally less than 20 feet thick while the sandstone can be as thick as 36 feet. The Hartselle Sandstone has varying thicknesses of bedded quartz sandstone layers and varies from 0 to 120 feet in thickness. The Pride Mountain Formation consists mostly of shale with some weathering. The weathering of the shale layers produces clay with chert. The shale is less than 350 feet thick and the clay is between 5 and 30 feet thick. The Tuscumbia Limestone, Fort Payne Chert, and Maury Formation contains thickly bedded limestone with chert, thinly bedded chert, and a thin layer of shale weathering into a weak clay. The limestone is less than 80 feet thick, the chert is about 90 to 200 feet thick, and the shale is 1 to 3 feet thick. The Bangor Limestone has medium to thickly bedded limestone and is less than 150 feet thick. ${ }^{[11]}$

The rock formations were deposited in the Silurian, Devonian, and Mississippian periods from approximately 443 million years to 331 million years ago. Since then, the area has been subjected to compressional forces which have formed the Appalachian Valley and Ridge province. The layers in the area of interest were folded and faulted during the compression. ${ }^{[10]}$ 


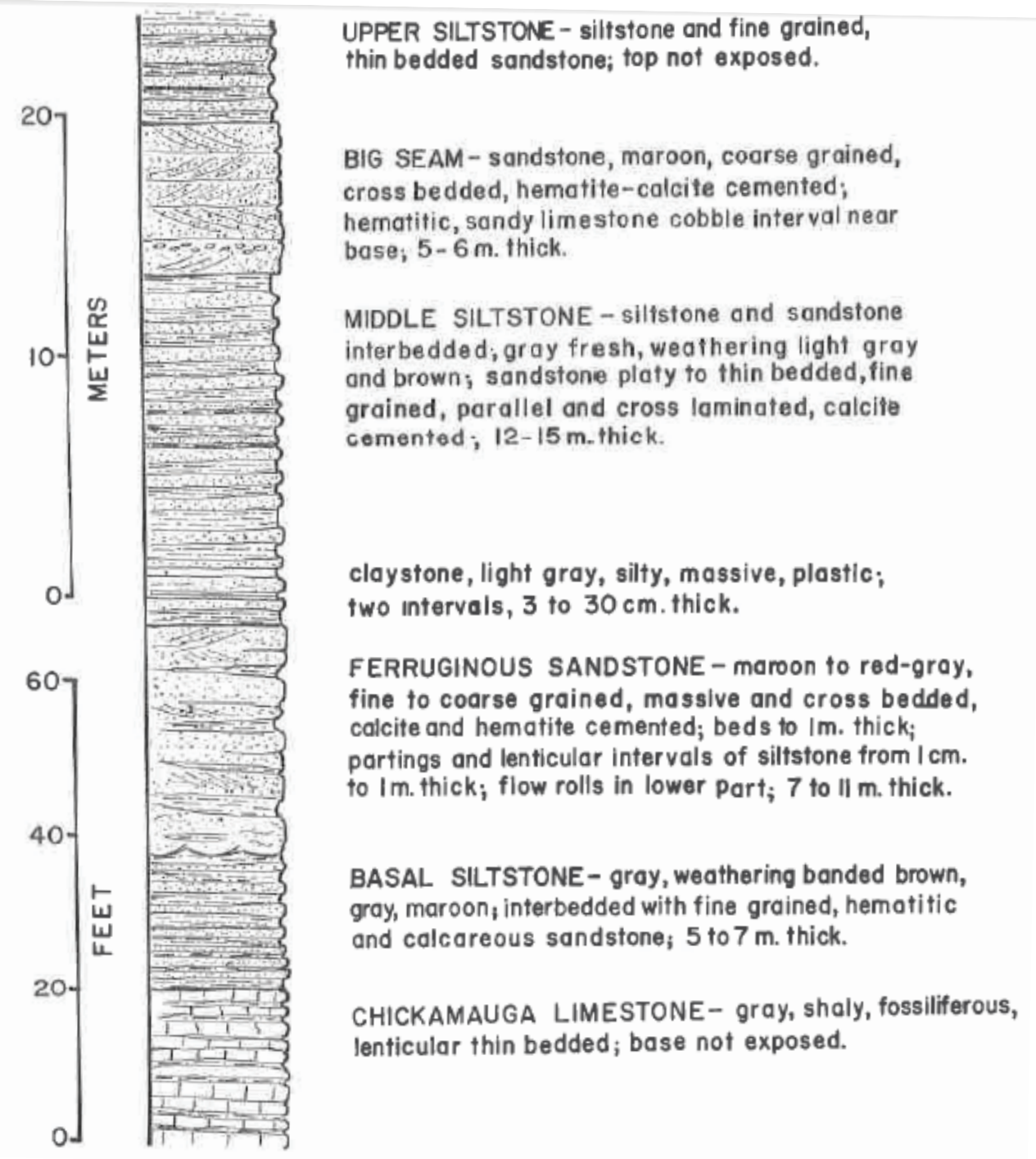

Figure 5: Assumed stratigraphy from Boring $1{ }^{[2]}$ SeE APPEndix fOr PERMissions. 


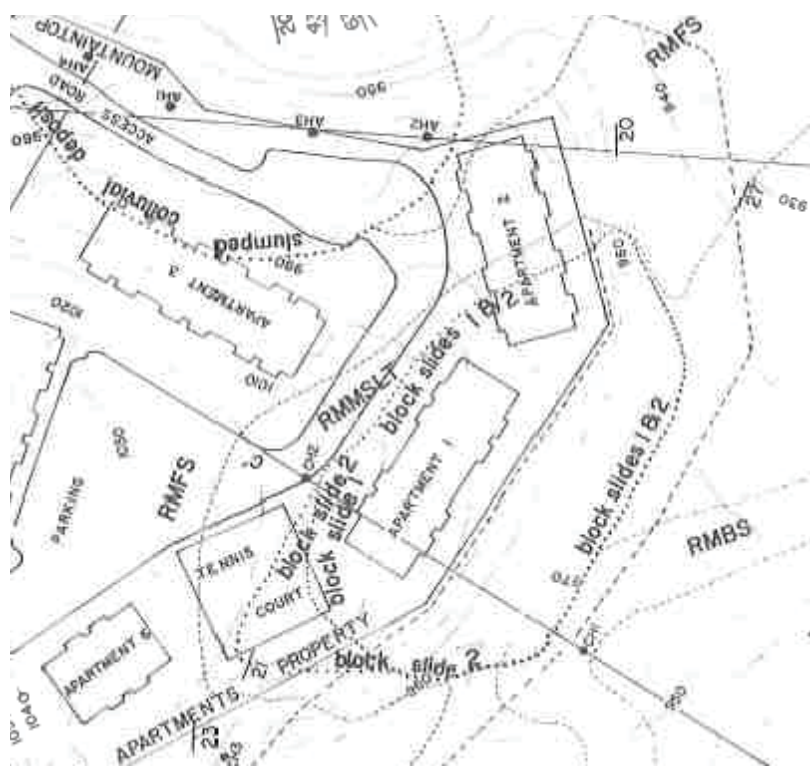

FIGURE 6: MOUNTAIN TOP APARTMENTS AND THE BLOCK SLIDES OUTLINED. ${ }^{[2]}$ SEE APPENDIX FOR PERMISSIONS.
The design company drilled five exploration borings within the construction site, which are shown on Figure 6. Boring 1 was the only hole within the perimeter of either ground movements, though Boring 2 was close to the edge of the second ground movement (Figure 6). The designing company then tested the strength of several of the rock layers. The soil groupings were classified into three groups: a clay/siltstone layer, a silt/sandstone layer, and limestone

layer. The strength values were averaged within those groups though the actual test values in each grouping varied widely. The averaged strength parameters are reported in Table 1. In addition, no strength tests were reported from Boring 1 . The design company used a cohesion of 1152 psf and a friction angle of 10 degrees to estimate of the stability of the final slope. The final slope encompassed the silt/sandstone and clay/siltstone layers, which included the clay seam that failed.

TABLE 1: THE STRENGTH PARAMETERS OF THE SOIL AND ROCK IN THE AREA OF INTEREST.

\begin{tabular}{|l|c|c|c|}
\hline Property & Clay/Siltstone & Silt/Sandstone & Limestone \\
\hline RQD & $40 \%$ & $85 \%$ & $95 \%$ \\
\hline Unit Weight & $133 \mathrm{pcf}$ & $144 \mathrm{pcf}$ & $150 \mathrm{pcf}$ \\
\hline Strength & $2300 \mathrm{psi}$ & $3300 \mathrm{psi}$ & $8000 \mathrm{psi}$ \\
\hline Cohesion & $6 \mathrm{psi}$ & $8 \mathrm{psi}$ & $9 \mathrm{psi}$ \\
\hline Friction Angle & $20^{\circ}$ & $37^{\circ}$ & $6^{\circ}$ \\
\hline
\end{tabular}




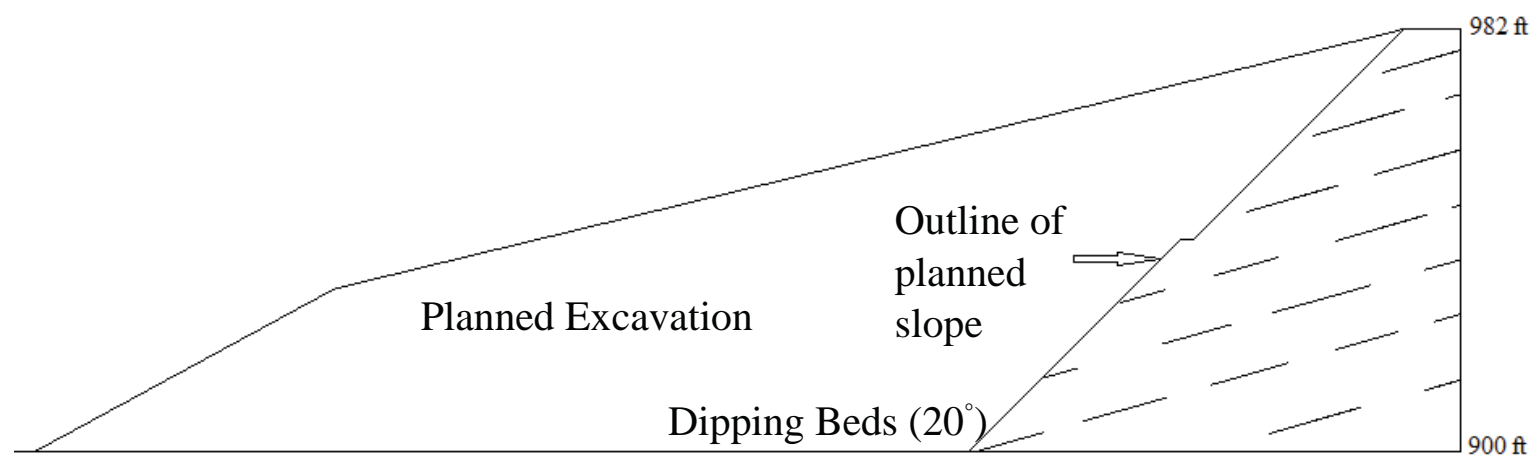

FIGURE 7: DESIGN OF CUT SLOPE DRAWN FROM INFORMATION IN THE DESIGNING COMPANY REPORT. ${ }^{\text {[1] }}$

Two additional issues were considered in evaluating the slope failure. The first issue was the potential for underground iron ore mines, while the second issue was the fracture systems in the rock. During exploration drilling no underground openings were encountered. However, there are historical records that indicate that there was at least

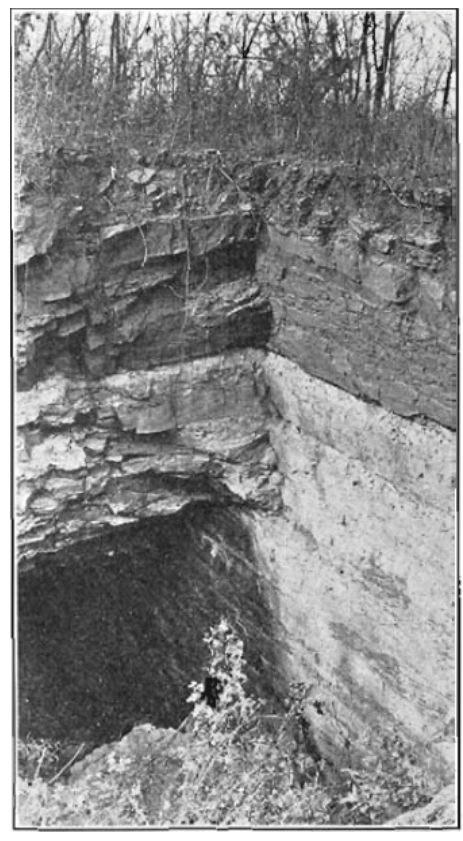

Figure 8: FROM CRANE'S PAPER SHOWING THE FRACTURE SYSTEMS. SEE APPENDIX FOR PERMISSIONS. one underground mine in the vicinity. While many underground iron mine locations are known some earlier mines in the surrounding area have unknown locations. ${ }^{[11]}$

In 1927, Walter R. Crane, working for the U.S. Bureau of Mines, described the issues of subsidence and drainage in the iron ore mines in the Birmingham, Alabama. Crane's main focus was the extensive fracture system that resulted in significant amounts of water entering into the underground mines. Crane identified two major joint sets, both relatively vertical and nearly perpendicular to each other (an example is seen in Figure 8). ${ }^{[4]}$ According to Crane's paper ${ }^{[4]}$, the vertical fractures contributed to mine collapses due to slipping along the fractures in the mine ceilings and the introduction of significant amounts of water. Crane also observes that the dual fracture system could also cause slope failure 
and surface subsidence for underground mines located on the Red Mountain slope. While the design company realized that the rock was fractured, they assumed that their slightly higher factor of safety would eliminate the risk from the fractures. ${ }^{[1]}$

The designing company designed two different slopes for the project. The first slope was designed to have a slope of 4 to 1 and contained two drainage outlets. The company deemed that the design was infeasible due to the cost of slope support needed. A second slope was designed to have an average slope of 1 to 1 and have a concrete drainage ditch. The cut was designed to vary according to the natural slope in order to increase stability. The cut was specifically designed to reduce the cost of support for the slope.

\subsection{MODELING}

Limit equilibrium analysis has been used for many years as a tool to analyze slope stability. The system simplifies complex situations to the ratio between driving and resisting forces, which allows for calculations to be much easier. In the past, the complexity of slope stability would cause the calculations to be too complicated to compute. Now, however, computers have made the process of calculating slope stability much faster and allows for more complexity. Current slope stability analysis programs allow fractures to be added without having to go through a long series of complex calculations. In addition, back analyses can now be conducted to determine the strength values of failure slopes. ${ }^{[7]}$ For example, an investigation of rock slides in a coal mine in Turkey, the authors, Ulyusay and Doyuran, conducted a back analysis to determine the strength of the rock at the point of failure. The need for the back analysis with computer assistance was due to the complexity of the rock structure. ${ }^{[12]}$ The fracture system, intermittent clay layers, and changing pore water pressure from Ulyusay and Doyuran paper are very similar to the conditions analyzed for the slope failure described in this report. Ulyusay and Doyuran used the slope stability program 
Slide, also from the Rocscience suite, to determine the causes of the failures at the coal mines.

To determine the cause of the landslides, the RocPlane stability program from Rocscience was used. RocPlane was chosen from the suite of programs because of the simplicity of the slope failure along a planar surface. RocPlane uses static equations to determine stability, comparing the driving forces to the resisting forces (see equations below). The driving forces are the weight of the slope and the resisting forces are the cohesion and friction between rock layers. The calculations are further complicated by the pore water pressure and fractures.

$$
\begin{gathered}
F_{y}=-W+V \cos \theta \\
F_{x}=V \cos \theta \\
N=-F_{y} \cos \alpha+F_{x} \sin \alpha-U \\
S=-F_{y} \sin \alpha-F_{x} \cos \alpha \\
\tau=c \cdot L+N \tan \varphi \\
\text { Factor of Safety }=\frac{\tau}{S}
\end{gathered}
$$

Where $F_{y}=$ vertical forces

$$
\begin{aligned}
& F_{x}=\text { horizontal forces } \\
& W=\text { weight of soil block } \\
& V=\text { pressure from water in tension cracks } \\
& \theta=\text { angle of the tension crack to the horizontal } \\
& N=\text { normal force } \\
& S=\text { shear force } \\
& \alpha=\text { angle between failure surface and horizontal } \\
& \tau=\text { shear strength } \\
& c=\text { cohesion of soil } \\
& L=\text { length of failure surface }
\end{aligned}
$$




$$
\varphi=\text { friction angle of soil }
$$

For this analysis, the RocPlane model utilized excavation data from the original plans of the design company and information from the investigative report. The combined data allows for a relatively accurate description of the slope at failure. The depths of the rock layers were determined from Boring 1 and elevation data provided by the design company. The reasoning behind using Boring 1 is that it was the only hole that was drilled within the first slope failure's perimeter. However, Boring 2 was just outside the perimeter of the second ground movement, but instability caused by the first landslide most likely caused the second landslide.

RocPlane can only utilize one set of soil or rock input parameters, so the strength values of the rock that failed were used. A baseline analysis was conducted that represents the analysis of the designing company. The model utilizes a cohesion of $1152 \mathrm{psf}$, a friction angle of 10 degrees, and no pore water pressure. The report stated that the factor of safety that the designing company calculated was 1.48. The RocPlane factor of safety came to 1.54 . This analysis is provided in the Apopendix.

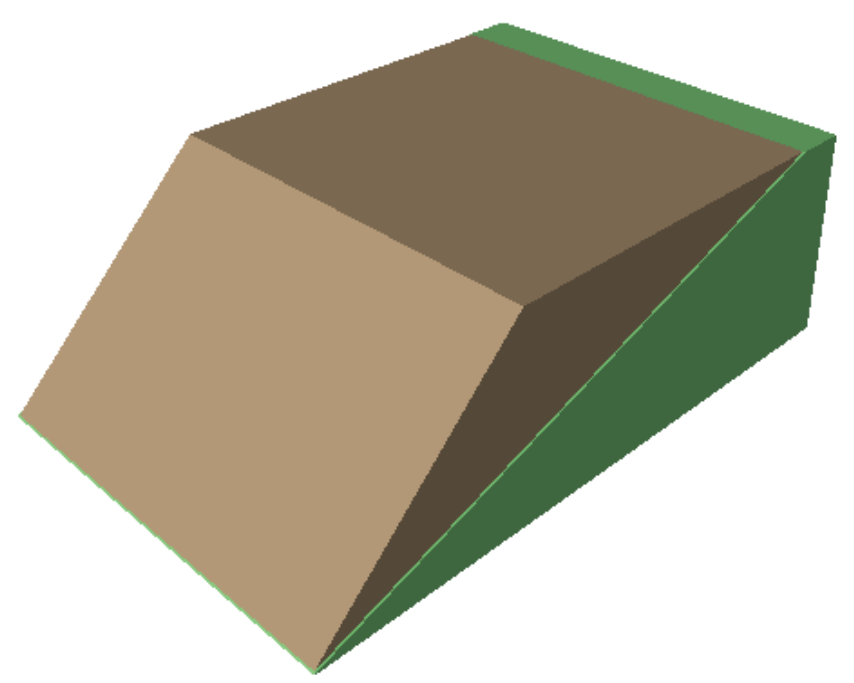

FIGURE 9: BASELINE MODEL THAT REPRESENTS AS DESIGNED FACTORS FROM THE DESIGNING COMPANY. 
After the baseline analysis was conducted, fractures were added. A single fracture could be input at a distance behind the crest of the slope, as shown below (Figure 10). In addition, the maximum pore water pressure was added to the base of the fractures, since the fractures would allow for easier water infiltration and correlate with the report of water seepage during the excavation. Also, Crane described water pouring into underground mines. The fractures would allow for the amount of water that Crane describes. ${ }^{[4]}$ In order to test the height at which a fracture could cause failure, the upper and lower slope faces were both set to $45^{\circ}$ (Figure 11), while the height versus factor of safety was graphed to determine the failure point (Figure 12).

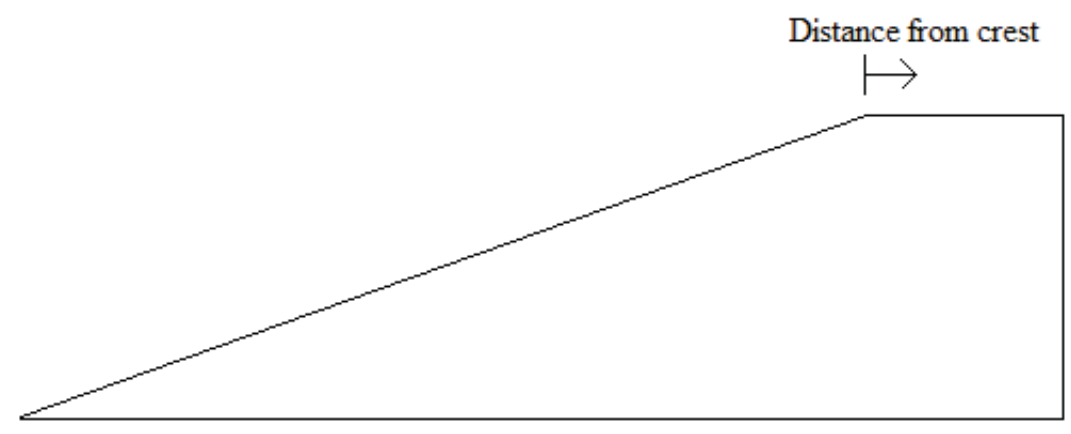

Figure 10: Demonstration of RocPlane's FRaCtURE InPUT SySTEM. 


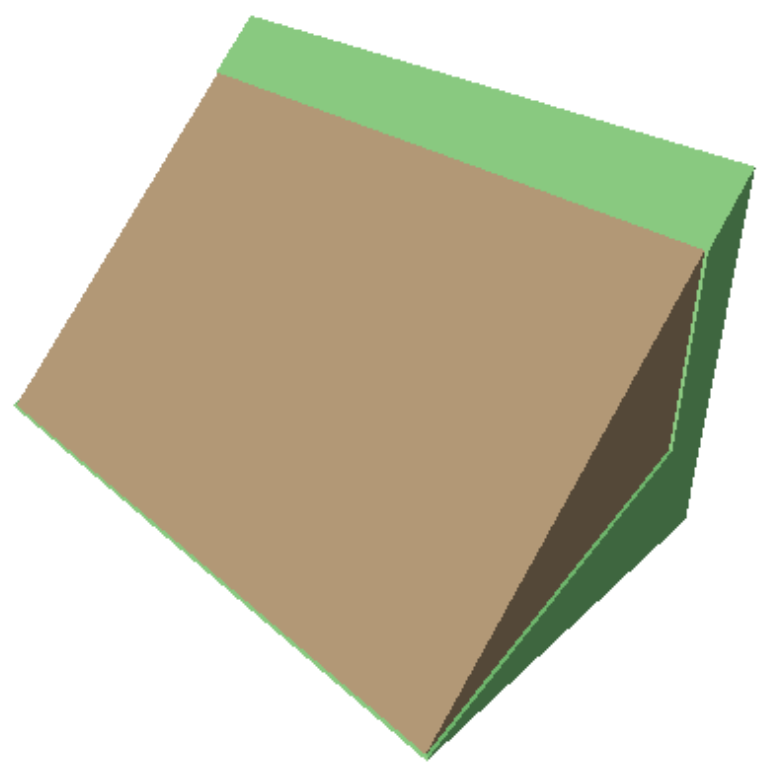

Figure 11: THE MODEL SHOWING A FACTOR OF SAFETY OF 1.0 AT 50 FEET WITH FRACTURES AND WATER PRESSURE AT THE BASE OF THE FRACTURES.

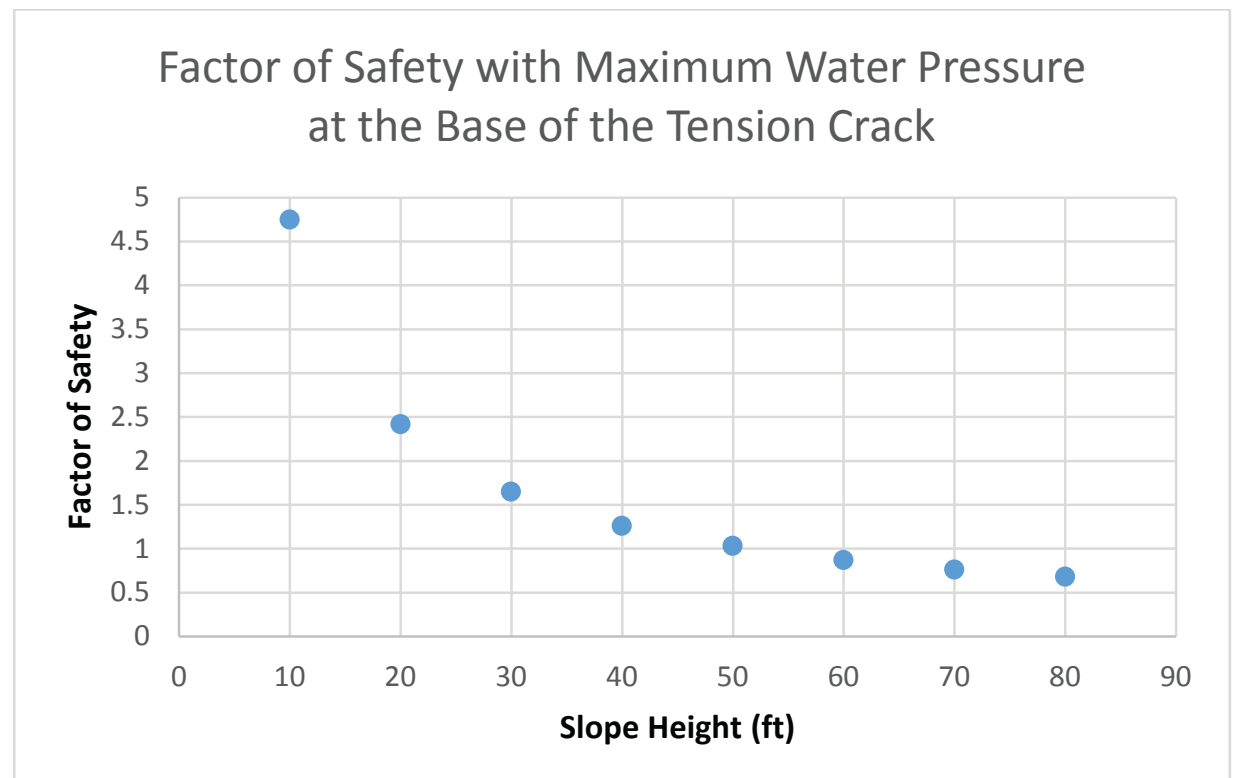

FIGURE 12: GRAPH OF THE FACTOR OF SAFETY VERSUS SLOPE HEIGHT WITH FRACTURES AND WATER PRESSURE AT THE BASE OF THE FRACTURE. 
As seen on the graph, the slope had a factor of safety of 1.0 at a slope height of about 50 feet with the maximum pore water pressure at the base of the fractures and the given soil strength parameters. This analysis is also provided in the Appendix.

\subsection{ANALYSIS}

The exploratory company noted that the landslide occurred along a small claystone seam in the rock layers. Because the design company averaged their values over significantly large groups of rock layers, the weak layer would have been masked to some degree. In addition, the design company stated that they did not encounter the groundwater table during their site investigation and therefore did not consider pore water pressures in their analysis.

The investigating company that reviewed the designing company's report was also concerned about the use of averaged strength values as well, since, as previously noted, the values documented in the design company's supporting documents varied widely, even within similar types of rock. The main concern of the investigating company, however, was the lack for consideration of the joint fracture system.

To address this issue, the next step of the modeling focused on the joint fracture system and the pore water pressure. As previously mentioned, the baseline model agreed with the design company's report, with some slight calculation differences resulting in the 0.06 factor of safety difference. When the fractures was added to the model along the pore water pressure distribution within the fractures, the factor of safety reduced to 1.0 at a height of approximately 50 feet. The maximum pore water pressure was added to the base of the fractures, which created a slightly lower factor of safety than if it had been left at the slope mid height. Because the fractures would allow for greater 
infiltration, it was assumed the greatest pressure would be at the base of the fractures. In comparison to the actual failure, the analysis of the fractures with maximum pore water pressure at the fractures' base matches the failure relatively well. The slope was excavated to a maximum of 65 feet and a block failure occurred along the claystone layer. ${ }^{[8]}$ The fractures would allow for a block failure and the model showed that the slope would have failed above approximately 50 feet, well within the 65 foot excavation.

\subsection{CONCLUSIONS}

In retrospect, the lack of understanding of the geology of the area as well as disregarding the pore water pressure caused the design to be inadequate. A baseline model was designed which accurately portrayed the design company's analysis. After that model was built, fractures and pore water pressure were then added to the system. The fractures were added because they were observed by the investigating companies and described by a 1927 paper by Crane. By including the pore water pressure in the analysis, the model correctly predicted the slope failure. The model showed that there was failure at a height of approximately 50 feet which is within the 65 foot excavation.

According to the analysis conducted, the results show that the investigating companies were correct in attributing the failure to the fracture system. More study would be needed to determine if underground mines at the site contributed to the failure. Blasting might have also been a factor in the failure, but a more detailed analysis would need to be conducted.

Two conclusions can be made from the analysis. First, the design company failed to consider previous studies that concerned the Birmingham area. Crane's 1927 paper would have described the extensive vertical fracture system that would cause pore water 
pressure to become a problem within the fractures even though the rock layers had very low permeability. Second, a plane failure analysis that included these factors would have predicted the consequences of the excavation.

\subsection{BIBLIOGRAPHY}

${ }^{[1]}$ Anderson Engineering and Testing Company. "Geotechnical Investigation for Proposed Eastwood Festival Center”. February 1987. Print.

${ }^{[2]}$ Barrett, Lonice C.; Reheis, Harold F.; and McLemore, William H. "Case studies in applied geology in the southeastern United States". Georgia Department of Natural Resources Environmental Protection Division Georgia Geologic Survey. April 6, 1989. Print.

${ }^{[3]}$ Burchard, Ernest F. and Butts, Charles. Iron Ores, Fuels, and Fluxes of the Birmingham District, Alabama. Washington Government Printing Office. 1910. Print.

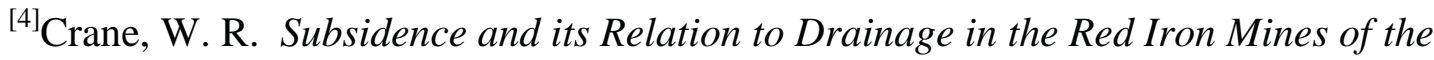
Birmingham District, Alabama. New York Meetings. February 1925 and February 1927. Print.

${ }^{[5]}$ Fletcher, C. Scott. "Review of Geotechnical Data". Atlanta Testing and Engineering. August 24, 1987. Print.

${ }^{[6]}$ Google. Maps. 2014. www.google.com/maps/. Web.

${ }^{[7]}$ Hossain, Md Monir. "Stability Analysis of Anchored Rock Slopes against Plane Failure Subjected to Surcharge and Seismic Loads”. May 2011. Ro.ecu.edu/au. Web.

${ }^{[8]}$ Law Engineering. "Preliminary Report of Observation Slope Failure Evaluation Eastwood Festival Centre". March 21, 1988. Print.

${ }^{[9]}$ National Climatic Data Center. Record of Climatological Observations, Station: Cahaba House, AL US. June 03, 2014. Requested from NOAA website.

${ }^{[10]}$ Raymond, Dorothy E.; Osborne, W. Edward; Copeland, Charles W.; and Neathery, Thornton L. Geological Survey of Alabama. 1988. www.gsa.state.al.us. Web. 
${ }^{[11]}$ Szabo, Michael W.; Beg, Mirza A.; Rheams, Lawrence J.; and Clarke, Otis M. Jr. 1979. Engineering Geology of Jefferson County, Alabama. University, Alabama. Print.

${ }^{[12]}$ Ulusay, Resat and Doyuran, Vedat. "Characteristics and geotechnical considerations of translational rock slides in a strip coal mine, SW Turkey”. Pages 529-535. Assessment and Prevention of Failure Phenomena in Rock Engineering. 1993. Books.google.com. Web.

\subsection{APPENDIX}

Figures 2 and 3

From Google @ Permission Guidelines for Google Maps and Google Earth

Google. 2014. Permissions. www.google.com/permissions. Web.

"Google Maps and Earth has built-in print functionality. You may print Content from Maps and Earth for personal use and enlarge it. In all uses where print will be distributed, first be sure to read our FAQ on applicable product Terms of Service and fair use. Second, all uses must properly show attribution to both Google and our data providers. Please see our attribution page for more information.

When using Google Maps and Earth Content in print, any images used must reflect how they would look on online. For example, you are not allowed to make any changes (e.g. delete, blur, etc.) to our products that would make them look genuinely different. This includes, but is not limited to, adding clouds or other natural elements, altered userinterfaces, and modification that do not appear in the actual product.

No explicit permission is required for your print project. We are unable to sign any letter or contract specifying that your project has our explicit permission."

"You can find the attribution in the line(s) shown on the bottom of the Content in the products along with copyright notices, such as "Map data (C2012 Google, Sanborn". Note that the exact text of the attribution changes based on geography and content type. The attribution text must be legible to the average viewer or reader."

Figures 4, 5, and 6 
Public documents from United States Geological Survey and Georgia Department of Natural Resources Environmental Protection Division Georgia Geologic Survey.

\section{Figure 8}

Dr. Vitton:

You have AIME's permission to use the photographs in the attached for your publication. Many thanks for contacting us on this.

Take care,

Michele

L. Michele Lawrie-Munro, CAE

Executive Director

American Institute of Mining, Metallurgical, and Petroleum Engineers, Inc. (AIME) 12999 East Adam Aircraft Circle

Englewood, CO 80112

Email: lawriemunro@aimehq.org

Phone: 1-303-325-5185

Fax: 1-888-702-0049

Website: www.aimehq.org

"The attached" refers to "Subsidence and Its Relation to Drainage in the Red Iron Mines of the Birmingham District, Alabama" by W.R. Crane in 1925 and 1927. 


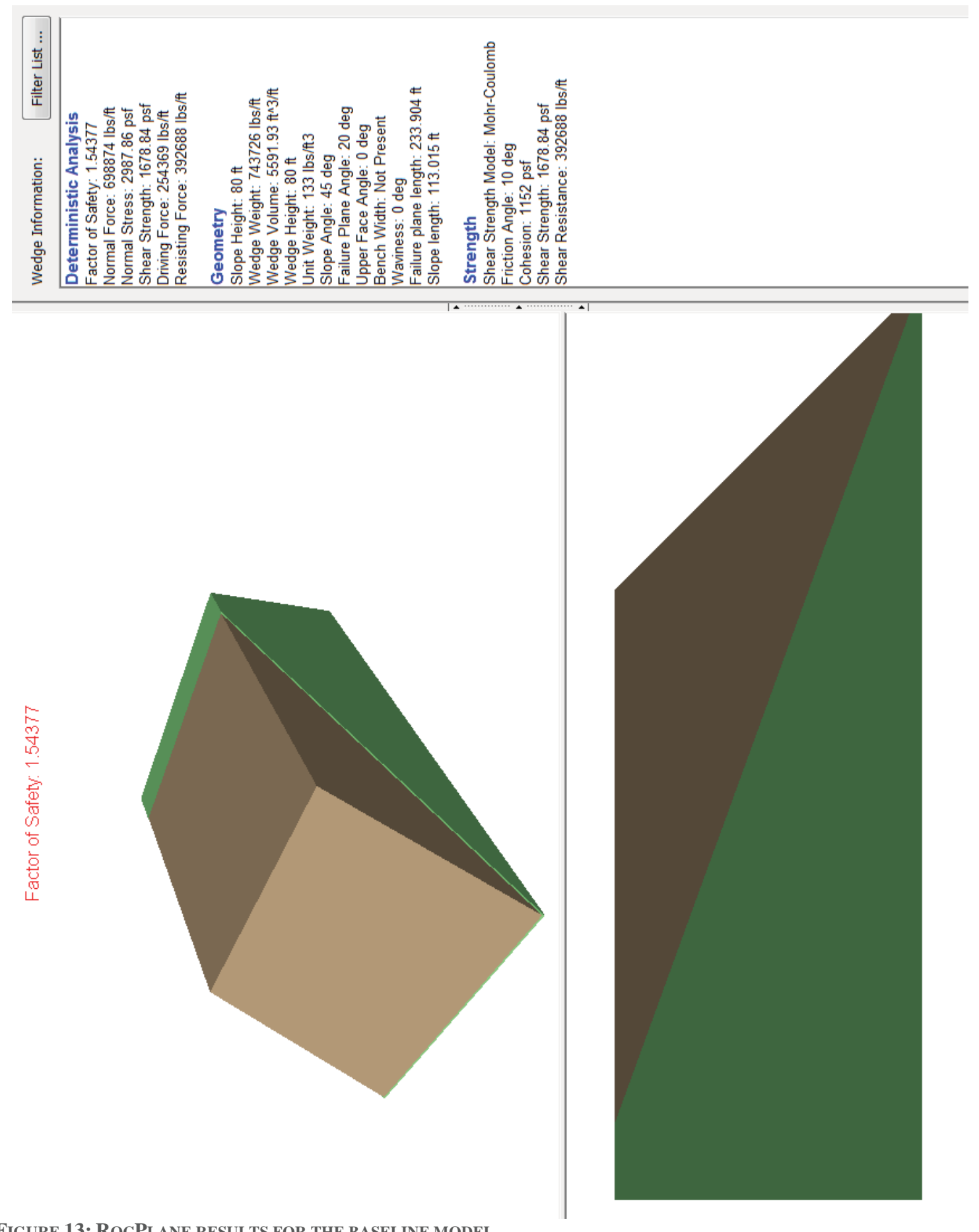

Figure 13: RocPlane RESUltS FOR THE BASELINE MODEL. 

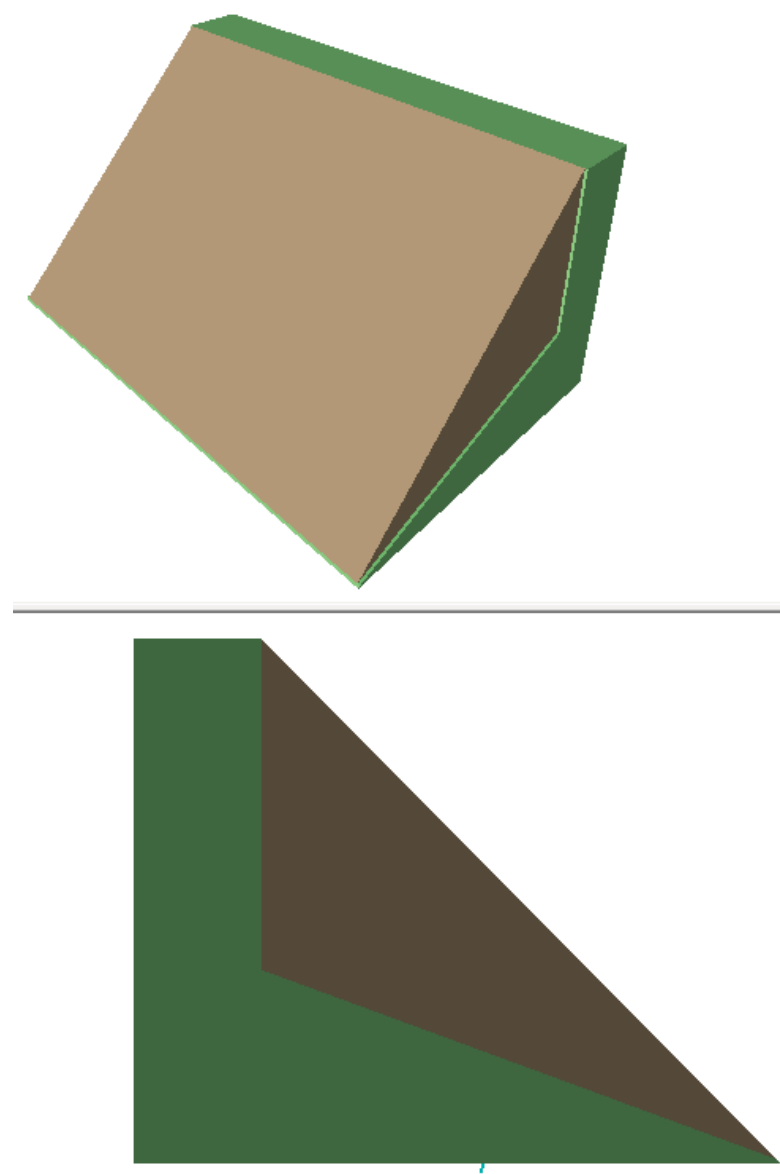

FiguRE 14: RoCPLANE RESULTS FOR THE AS FAILED MODEL.
Deterministic Analysis

Factor of Safety: 1.00245

Normal Force: $28979.3 \mathrm{lbs} / \mathrm{ft}$

Normal Stress: $605.147 \mathrm{psf}$

Shear Strength: $1084.26 \mathrm{psf}$

Driving Force: $53310.9 \mathrm{lbs} / \mathrm{ft}$

Resisting Force: 53441.6 lbs/tt

Geometry

Slope Height: $45 \mathrm{ft}$

Wedge Weight: $85649.4 \mathrm{lbs} / \mathrm{tt}$

Wedge Volume: $643.98 \mathrm{ft}^{\wedge} 3 / \mathrm{At}$

Wedge Height: $45 \mathrm{ft}$

Unit Weight: $133 \mathrm{lbs} / \mathrm{tt} 3$

Slope Angle: $45 \mathrm{deg}$

Failure Plane Angle: $20 \mathrm{deg}$

Upper Face Angle: 0 deg

Bench Width: Not Present

Waviness: 3 deg

Slope length: $63.5708 \mathrm{ft}$

Tension Crack Length: $28.6213 \mathrm{ft}$

Failure Plane length: $47.888 \mathrm{ft}$

Tension Crack: Presen

Tension Crack Angle: 90 deg

Distance From Crest: $0 \mathrm{ft}$

Tension Crack Length: $28.6213 \mathrm{ft}$

Strength

Shear Strength Model: Mohr-Coulomb

Friction Angle: 20 deg

Cohesion: 864 psf

Shear Strength: 1084.26 psf

Shear Resistance: $51922.8 \mathrm{lbs} / \mathrm{ft}$

Water Pressure: Present

Water Unit Weight: $62.4 \mathrm{lbs} / \mathrm{ft} 3$

Pressure Distribution Model: TC Base

Percent Filled TC: $100 \%$

gnore Failure Plane Pressure: NO

Water Force on Failure Plane: 42763.3

lbs/ft

Water Force on Tension Crack Plane

$25558.4 \mathrm{lbs} / \mathrm{ft}$

Factored Water Force on Tension Crack Plane: 25558.4 lbs/ft 